\section{Л.А. Ковалевич, ст. викладач \\ В.Г. Левицький, к.т.н., доц. Д.М. Білобров, аспірант \\ Н.П. Кириленко, пров. спеціаліст \\ B.I. Шамрай, к.т.н.}

Державний університет «Житомирська політехніка»

\title{
Динаміка споживання паливно-мастильних матеріалів самоскидами на Омелянівському родовищі гранітів
}

\begin{abstract}
Проаналізовано структуру споживання палива на різних етапах транспортного циклу, на основі якої встановлено основні напрями моніторингу роботи транспортних засобів та дотримання технологічного й організаційного режимів. Розраховано інтегральний нормативний коефіиієнт автосамоскидів. Також проведено розрахунок потреби в дизельному паливі та моторному мастилі самоскидів в умовах щебеневого Омелянівського кар'єру. Визначені витрати паливно-мастильних матеріалів на родовищі самоскидами залежно від пори року. Встановлено, що експлуатаційні затрати на паливно-мастильні матеріали для кар'єрних самоскидів залежно від їх вантажопідйомності становлять $20 \%$ від загальних затрат, пов'язаних з їх експлуатацією. Отримано залежність величини потужності на одиницю вантажопідйомності кар'єрного автотранспорту від їх вантажопідйомності. Визначено затрати палива залежно від відстані транспортування $i$ глибини родовища. Облік затрат мастильних матеріалів свідчить, щяо співвідношення між затратою мастила і палива становить залежно від періоду року від $6 \%$ (для зими) до $12 \%$ (для літа). Зниження затрати мастила можливе лише за рахунок його регенерації, яка здійснюється на спеціалізованій установці.
\end{abstract}

Ключові слова: паливо; споживання; режим роботи; кар'єр; відстань транспортування, корисна копалина; транспортний цүикл; інтегральний нормативний коефіцієнт автосамоскидів.

Актуальність теми. Автомобільні системи - одна з найскладніших галузей для проєктування та застосування електронних систем із вбудованим програмним забезпеченням для зв'язку та управління датчиками, виконавчими механізмами, мікропроцесорами та мережами. Нещодавні досягнення в галузі кар'єрного транспорту констатують нові системні підходи до вирішення сучасних викликів [1-15]. Нині для видобутку щебеневої сировини задіяно 6 автосамоскидів таких марок: типу БелАЗ (3 шт.) 3 вантажопідйомністю 30 т і Foton Auman (3 шт.) з вантажопідйомністю 13 т. На цих кар'єрних самоскидах як двигуни внутрішнього згоряння використовують двигуни, вироблені Ярославським та Уральським автозаводами з V-подібним розташуванням робочих циліндрів і газотурбінним нагнітачем. Система подачі палива виконана з безпосереднім впорскуванням повітря та очищенням повітря фільтрами із сухими елементами.

Офіційні джерела, які регулюють витрату палива на машино-годину, вказують, що 1 маш. год містить час технологічних операцій, час переміщення обладнання в межах будівельного майданчика, час технологічних перерв у роботі (на початку зміни - для виконання підготовчих операцій та технічного обслуговування; під час зміни - для відпочинку та особистих потреб; у кінці зміни - для виконання заключних операцій).

Мета статті - проаналізувати структуру споживання палива на різних етапах транспортного циклу, на основі якої встановити основні напрями моніторингу роботи транспортних засобів та дотримання технологічного й організаційного режимів.

Викладення основного матеріалу. Визначаючи кількість палива для машини під час зміни, необхідно помножити витрату палива за машино-годину роботи на фактичну кількість годин роботи механізму.

У чинному законодавстві норми витрат пального та мастильних матеріалів для будівельної техніки зазначені в таких нормативних актах:

1) ДБН В.2.8-12-2000 «Типові норми затрат пального і змащувальних матеріалів для експлуатації техніки в будівництві», затверджені Наказом Держбуду України від 12.01.2000 р. № 9 і введені в дію з 01.07.2000 р.;

2) норми затрат палива й мастильних матеріалів на автотранспорті, затверджені Наказом Міністерства транспорту України від 10.02.1998 р. № 43.

Потреба в дизельному паливі для всіх працюючих самоскидів у кар'єрі розраховується за ДБН В.2.8-12-2000 за такою формулою:

$$
H_{\text {in }}=q_{e} \cdot N_{e} \cdot C \cdot 10^{-3},
$$

де $H_{\text {in }}$ - індивідуальна норма затрати палива, кг/маш. год; 
$q_{e}$ - питома затрата палива при нормальній потужності двигуна, г/к.с.·год (за даними інструкції 3 експлуатації);

$N_{e}$ - номінальна потужність двигуна, к.с. (за даними інструкції з експлуатації);

$C$ - інтегральний коефіцієнт, який враховує середні умови експлуатації машини протягом робочої зміни і визначається окремо за формулою, наведеною нижче;

$10^{-3}$ - перевідний коефіцієнт грамів у кілограми.

Розрахунок інтегрального нормативного коефіцієнта:

$$
C=K_{д в} \cdot K_{д N} \cdot K_{T N} \cdot K_{T 3}
$$

де $K_{д в}$ - коефіцієнт використання двигуна в часі;

$K_{\text {дN }}-$ коефіцієнт використання двигуна за потужністю;

$K_{T N}$ - коефіцієнт, що враховує зміни питомої затрати пального залежно від ступеня використання двигуна за потужністю;

$K_{T 3}$ - коефіцієнт, який враховує затрату пального на запуск і регулювання роботи двигуна, а також щомісячне технічне обслуговування машин на початку зміни, дорівнює 1,03.

Результати розрахунку інтегрального нормативного коефіцієнта за формулою (2) для самоскидів, що працюють на Омелянівському родовищі, наведено в таблиці 1.

За відсутності стандартів або технічних даних, необхідних для розрахунку, в технічній документації виробника самоскида, проводяться контрольні вимірювання витрати палива.

Розрахунок тимчасових лінійних норм проводиться за одну годину роботи самоскида (л/год), за одну технологічну операцію (л) або за пробіг самоскида під час виконання спеціальних робіт (л/100 км).

Розрахунок інтегрального нормативного коефіцієнта автосамоскидів

Таблиияя 1

\begin{tabular}{|c|c|c|c|c|c|}
\hline Тип (марка) машини & Інтегральний коефіцієнт & $K_{\not B}$ & $K_{\not N}$ & $K_{T N}$ & $K_{T 3}$ \\
\hline БелА3-7540A & 0,531 & 0,86 & 0,4 & 1,5 & 1,03 \\
\hline Foton BJ 3251 & 0,425 & 0,86 & 0,4 & 1,2 & 1,03 \\
\hline
\end{tabular}

Кількість контрольних вимірювань має бути не менше трьох. Результати вимірювань оформлюються у відповідний акт, одна із засвідчених копій якого надсилається на розгляд у ДП «ДержавтотрансНДІпроект», реєструється та повертається підприємству (п. 2.2.3 Наказу № 43). Тимчасова індивідуальна норма споживання палива набирає чинності після його реєстрації та затвердження наказом керівника підприємства.

Розрахунок потреби в дизельному паливі самоскидів Омелянівського родовища приведено в таблиці 2.

Розрахунок потреби в дизельному паливі самоскидів

Таблиия 2

\begin{tabular}{|c|c|c|c|c|c|}
\hline $\begin{array}{c}\text { Тип (модель) } \\
\text { машини }\end{array}$ & $\begin{array}{c}\text { Потужність } \\
\text { двигуна } N_{e}, \text { к.с. } \\
\text { (кВт) }\end{array}$ & $\begin{array}{c}\text { Питома затрата } \\
\text { пального } q_{e}, \\
\text { г/к.с.·год }\end{array}$ & $\begin{array}{c}\text { Інтегральний } \\
\text { коефіцієнт }\end{array}$ & $\begin{array}{c}\text { Норма затрати } \\
\text { палива } H_{\text {in, }} \\
\text { кг/маш. } \text { год. }\end{array}$ & $\begin{array}{c}\text { Річні затрати } \\
\text { палива*, т/рік }\end{array}$ \\
\hline $\begin{array}{c}\text { БелАЗ-7540 } \\
\text { (3 шт.) }\end{array}$ & $420(309)$ & 228 & 0,531 & 50,85 & 423,0 \\
\hline $\begin{array}{c}\text { Foton ВЈ 3251 } \\
\text { (3 шт.) }\end{array}$ & $336(250)$ & 202 & 0,425 & 28,85 & 240,0 \\
\hline
\end{tabular}

*річна кількість робочих днів 260 у 2 зміни по 8 год

Отже, потреба дизельного палива становить 663 т у рік.

Потреба в моторних оливах для всіх працюючих самоскидів розраховується за такою формулою:

$$
H_{\text {iм }}=q_{\text {eм }} \cdot H_{\text {in }} \cdot 10^{-2} / \rho_{\partial},
$$

де $H_{\text {iм }}$ - річні затрати моторних мастил, л/рік;

$q_{e s}$ - питома затрата моторних мастил, л/100 л (за даними інструкції з експлуатації);

$H_{\text {in }}$ - річні затрати дизельного палива, кг/рік;

$\rho_{\partial}$ - густина дизельного палива, 0,85 кг/л.

Потреба в моторних мастилах вказана у таблиці 3.

Таблиияя 3

\begin{tabular}{|c|c|c|c|c|}
\hline $\begin{array}{c}\text { Тип (модель) } \\
\text { машини }\end{array}$ & $\begin{array}{l}\text { Річні затрати } \\
\text { палива, л/рік }\end{array}$ & $\begin{array}{c}\text { Питома затрата мастил } \\
q_{e \mu}, \pi / 100 \text { л }\end{array}$ & $\begin{array}{c}\text { Річні затрати мастил } \\
H_{\text {iм }}, \text { л/рік }\end{array}$ & $\begin{array}{c}\text { Річні затрати мастил } \\
H_{\text {in }}{ }^{*}, \mathrm{~T} / \mathrm{pi \kappa}\end{array}$ \\
\hline БелАЗ-7540A & 497647 & 4,3 & 21399 & 19,26 \\
\hline Foton BJ 3251 & 282353 & 3,2 & 9035 & 8,13 \\
\hline
\end{tabular}

Розрахунок потреби в моторних мастилах самоскидів

*при густині моторного мастила 0,9 кг/л 
Отже, потреба моторних мастил становить 27,4 т у рік.

Нормативи затрат мастил знижуються на 50 \% для всіх самоскидів, що експлуатуються до 3-х років. Нормативи підвищуються до 20 \% для самоскидів, що експлуатуються більше 8-ми років.

Для умов Омелянівського родовища потреби в паливі та мастилі варіюються від пори року, що наведено в таблиці 4 і на рисунку 1.

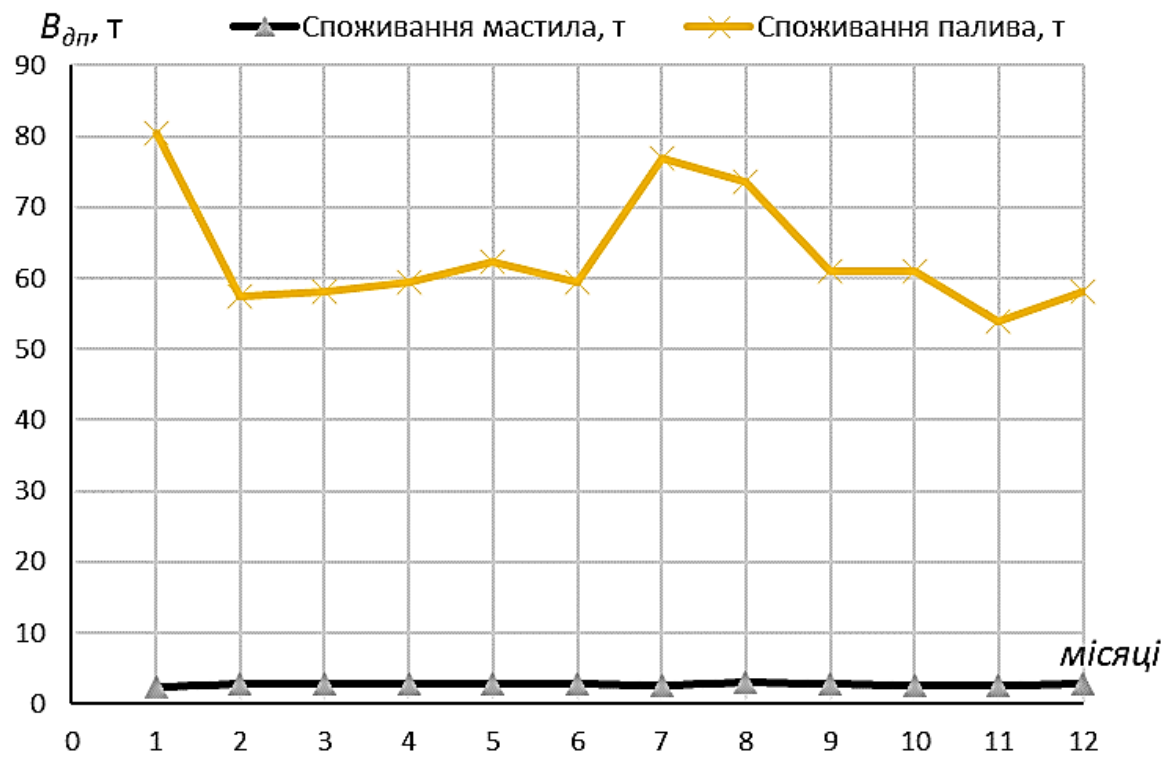

Рис. 1. Витрати паливно-мастильних матеріалів на родовищі самоскидами залежно від пори року

Таблиия 4

Витрати ПММ на Омелянівському родовищі самоскидами залежно від пори року

\begin{tabular}{|l|c|c|c|}
\hline \multicolumn{1}{|c|}{ Період року } & Літо & Перехідний період & Зима \\
\hline Витрата дизельного палива, т & 211,7 & 368,5 & 196,0 \\
\hline Витрата мастил, т & 8,4 & 14,7 & 7,8 \\
\hline $\begin{array}{l}\text { Витрати дизельного палива і } \\
\text { мастил, \% }\end{array}$ & $27 \%$ & $47 \%$ & $26 \%$ \\
\hline
\end{tabular}

Аналіз витрат дизельного палива протягом року свідчить, що в середньому за один місяць витрачається 82 т палива, при цьому в січні й серпні фіксується підвищений рівень витрат, що більший середній на 20-30\%. Це пов'язано 3 кліматичними умовами в січні, а в серпні - 3 підвищенням продуктивності видобування гірської маси.

Експлуатаційні затрати на паливно-мастильні матеріали для кар'єрних самоскидів залежно від їх вантажопідйомності становлять 20 \% від загальних затрат, пов’язаних з їх експлуатацією (табл. 5, рис. 2).

Експлуатаційні затрати на ПММ залежно від вантажопідйомності самоскидів

Таблиия 5

\begin{tabular}{|c|c|c|c|}
\hline Вантажопідйомність, т & Затрати на пальне, $\%$ & Затрати на мастила, $\%$ & Загальні затрати на ПММ, $\%$ \\
\hline 32 & 13 & 5 & 18 \\
\hline 45 & 15 & 5 & 20 \\
\hline 68 & 18 & 6 & 24 \\
\hline 91 & 24 & 8 & 32 \\
\hline
\end{tabular}

Аналіз даних, наведених у таблиці 5 та на рисунку 2, свідчить, що максимальна вартість паливномастильних матеріалів припадає на роботу самоскидів вантажопідйомністю 90 т, а при збільшенні або зменшенні вантажопідйомності ці витрати незначно зменшуються. Цей факт пояснюється, зокрема, тим, що у випадку використання самоскидів вантажопідйомністю понад 90 т різко зростає вартість шин, технічне обслуговування і ремонт таких самоскидів, що призводить до відносного зменшення витрат на паливо. При цьому в абсолютному вираженні вартість паливно-мастильних матеріалів залежно від вантажопідйомності самоскидів збільшується. 


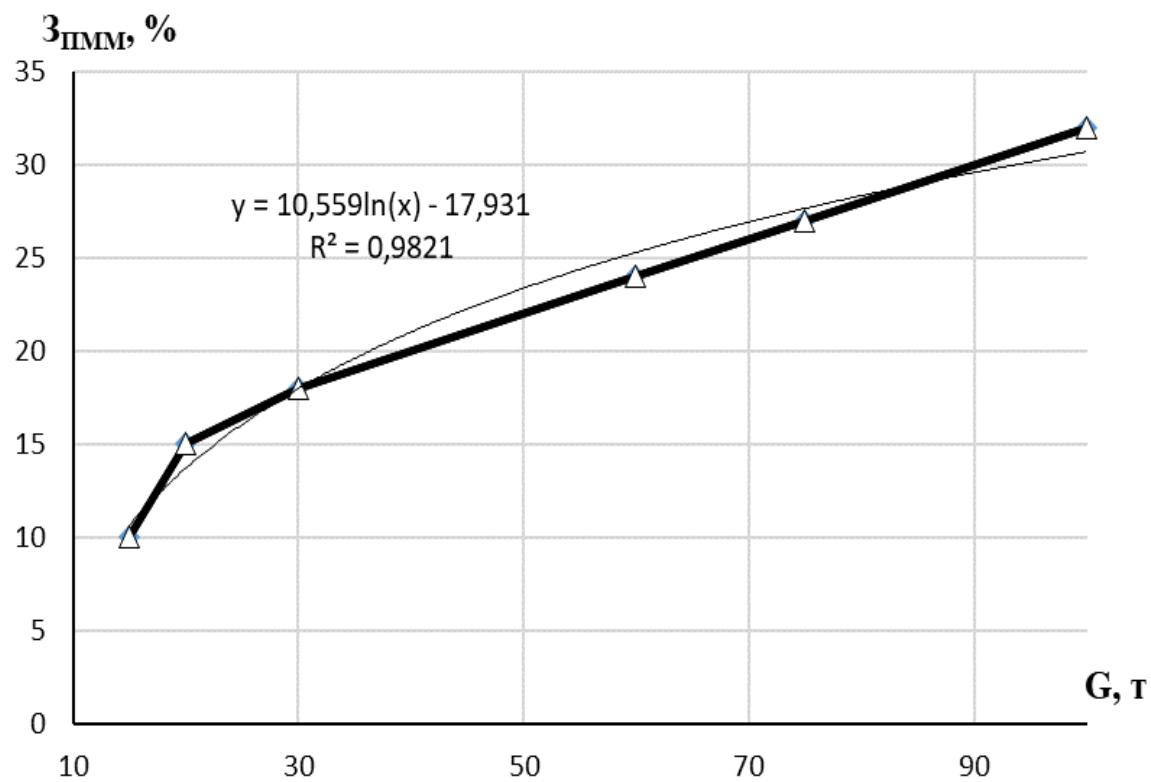

Рис. 2. Експлуатаційні затрати на паливно-мастильні матеріали кар'єрних самоскидів залежно від їх вантажопідйомності

Аналізуючи технічні характеристики кар'єрних самоскидів, а також потужність встановлених на них двигунів, слід зазначити, що самоскиди вантажопідйомністю близько 90 т мають найкращі силові характеристики на одиницю вантажопідйомності, що дорівнює $(6,2-7,2)$ кВт/т (рис. 3).

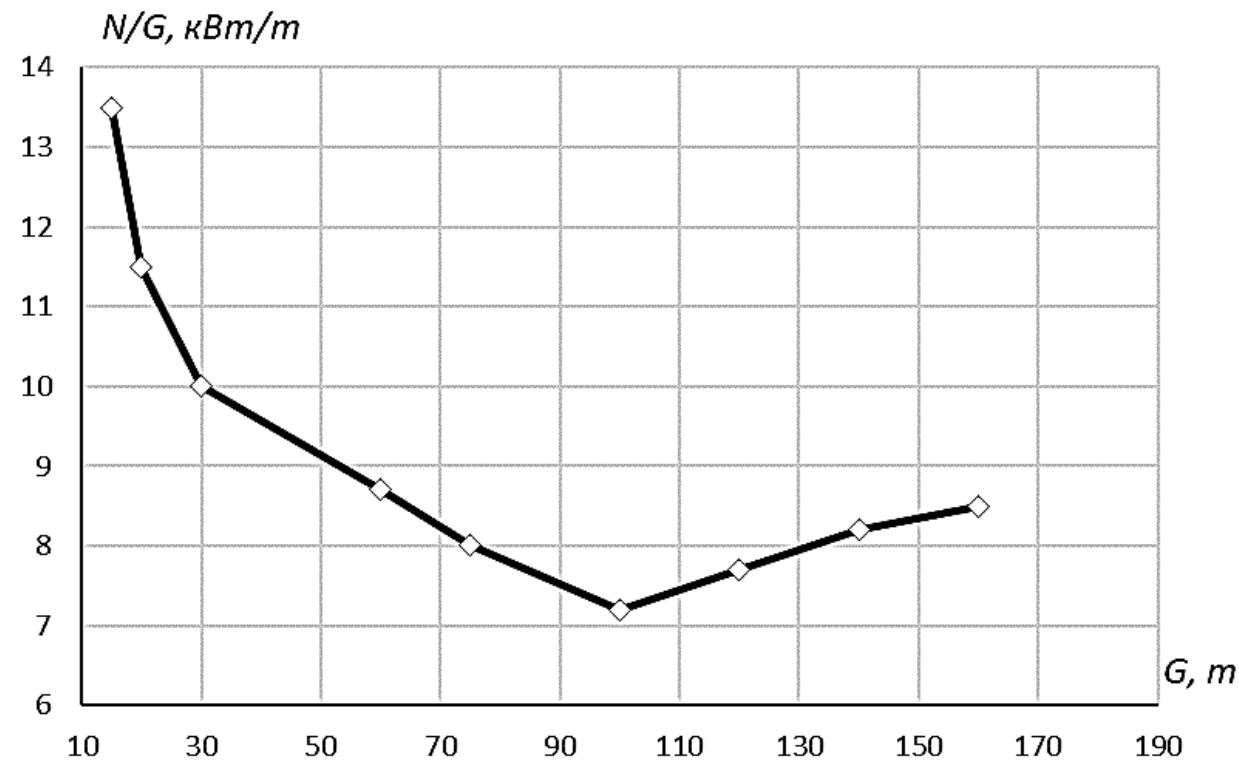

Рис. 3. Залежність величини потужності на одиницю вантажопідйомності кар 'єрного автотранспорту від їх вантажопідйомності

Витрати палива у самоскида залежать від ваги самого самоскида та його відношення до корисного навантаження, а також від стадії транспортного циклу й відстані транспортування корисної копалини. Збільшення транспортної відстані зменшує споживання палива на 20-30 \%.

Дослідження встановило структуру споживання палива самоскидами БелАЗ для транспортного циклу. Загальна затрата палива складається із затрати палива під час очікування, завантаження, розвантаження $\left(Q_{d}=Q_{o}+Q_{n}+Q_{p}\right)$, затрати палива при переміщенні порожнього самоскида $\left(Q_{p}\right)$, витрати пального на рух завантаженого самоскида $\left(Q_{3}\right)$, що в свою чергу складається з витрат на підняття спорядженої ваги самоскида $\left(Q_{c}\right)$ і транспортування гірської маси $\left(Q_{2}\right)$ :

$$
Q_{m}=Q_{d}+Q_{n}+Q_{3}
$$


Залежно від відстані транспортування гірської маси для умов Омелянівського родовища отримано дані про затрати палива для самоскидів БелАЗ, що зведені в таблиці 6.

Таблиия 6

Затрати палива залежно від відстані транспортування і глибини родовища

\begin{tabular}{|c|c|c|}
\hline \multirow{2}{*}{ Затрата палива $Q_{m}, \%$} & $h=12 \mathrm{M}, L=1 \mathrm{\kappa м}$ & $h=24 \mathrm{M}, L=3,6$ км \\
\cline { 2 - 3 } & 100 & 100 \\
\hline$Q_{d}$ & 11 & 4 \\
\hline$Q_{n}$ & 13 & 42 \\
\hline$Q_{c}$ & 32 & 42 \\
\hline$Q_{2}$ & 44 & 42 \\
\hline
\end{tabular}

Дані в таблиці показують, що зі збільшенням транспортної відстані структура споживання палива різко змінюється щодо споживання палива під час очікування, завантаження та розвантаження, що призводить до його відносного зменшення майже утричі. Частка палива, затраченого під час руху самоскида 3 гірською масою, становить 74-80 \% від загальної вартості рейсу, і в цей час потужність двигуна фактично використовується в повному обсязі. Економія палива на цьому етапі транспортної схеми можлива завдяки обліку та використанню технологічних факторів, а саме завдяки вибору та формуванню оптимального в усіх відношеннях маршруту перевезення.

У свою чергу решта загального споживання пального, коли самоскид порожній, завантажується i розвантажується, не перевищує 12-22 \%, тоді як потужність двигуна використовується лише на $30 \%$. Завдяки цьому існує значна економія палива при експлуатації кар'єрних самоскидів.

Отже, теоретично затрата палива - це сума двох величин, перша з яких визначає затрату палива під час руху самоскида з гірською масою, а друга - палива, спожитого під час руху порожнім, а також завантаження та розвантаження самоскида. Але практично в цьому співвідношенні слід враховувати також паливо, яке непродуктивно витрачається в результаті відхилення самоскида від заданого маршруту внаслідок непередбачених затримок з виїздом на маршрут і передчасного повернення в гараж, а також несанкціонованого зливу палива та його неповне заправлення.

Дані за фактичною затратою дизельного палива на Омелянівському родовищі, зведені в таблиці 7, свідчать, що обладнання самоскидів системою нормування затрати палива і включення її в інформаційну систему управління автомобільним транспортом дозволило скоротити затрати палива за рахунок контролю за невиробничими операціями майже на 6 \%.

Облік затрат мастильних матеріалів показує, що співвідношення між затратою мастила і палива становить залежно від періоду року від $6 \%$ (для зими) до $12 \%$ (для літа). Зниження затрати мастила можливе лише за рахунок його регенерації, яка здійснюється на спеціалізованій установці.

Таблиия 7

Динаміка затрат дизельного палива на Омелянівському родовищі

\begin{tabular}{|c|c|c|c|}
\hline Показники & За 2018 рік & За 2019 рік & Зміна показників, \% \\
\hline Кількість машин, шт. & 6 & 6 & - \\
\hline Відстань транспортування, км & 3,6 & 3,6 & - \\
\hline Затрата дизельного палива, т & 920 & 980 & 6 \\
\hline
\end{tabular}

\section{Висновки:}

1. Експлуатаційні витрати на паливно-мастильні матеріали залежно від вантажопідйомності становлять близько 20 \% від загальних матеріальних витрат на експлуатацію транспортних засобів.

2. Проаналізовано структуру споживання палива на різних етапах транспортного циклу, на основі якої встановлено основні напрями моніторингу роботи транспортних засобів та дотримання технологічного й організаційного режимів.

3. Система контролю затрати палива дозволяє зменшити затрату палива та забезпечити оптимальний режим роботи автомобілів.

4. Система моніторингу обліку затрат пального самоскидом на всіх етапах його експлуатації (завантаження, розвантаження, транспортування та переміщення в порожньому стані) 3 одночасним контролем швидкості та ваги, що дозволяє виявити несанкціонований злив палива, неповне заправлення, відхилення від вказаного маршруту, невиробничі поїздки.

\section{Список використаної літератури:}

1. Hanxleden R. A co-design approach for safety-critical automotive applications / R.Hanxleden, A.Botorabi, S.Kupczyk // IEEE Micro (Special Issue on Embedded Fault-Tolerant Systems). - 1998. - Vol. 18. - P. 66-79. 
2. Kassakian J.G. Automotive electrical systems - The power electronics market of the future : in Proc. IEEE APEC 2000 / J.G. Kassakian. - Vol. 1. - P. 3-9.

3. Brown G.M. A GTO powered AC drive system increases the performance of off-highway haul trucks : in Conf. Rec. IEEE-IAS Annu. Meeting, Oct. 3-7, 1999 / G.M. Brown, W.G. Koellner. - P. 222-233.

4. Brown G.M. Increased productivity with AC drives for mining excavators und haul trucks : in Conf. Rec. IEEE-IAS Annu. Meeting / G.M. Brown, B.J. Ebacher, W.G. Koellner. - 2000. - Vol. 1. - P. P28-P37.

5. Feasibility study to reduce injuries and fatalities caused by contact of cranes, drill rigs, and haul trucks with high tension lines / H.K. Sacks, J.C. Cawley, G.Homce, M.Yenchek // IEEE Trans. Ind. Applicat. - 2001. -Vol. 37. P. 914-919.

6. Криворучко A.O. Розробка узагальненої методики геометризації масивів природного каменю 3 метою отримання комплексної моделі родовища / А.О. Криворучко, В.В. Коробійчук, С.С. Іськов // Вісник ЖДТУ. 2012. - № 4 (63). - C. 190-202.

7. Weakening of rock strength under the action of cyclic dynamic loads / V.Korobiichuk, V.Kravets, R.Sobolevskyi et al. // Eastern European Journal of Advanced Technologies. - 2018. - Issue 2 (5). - P. 20-25.

8. Shamrai V. Management of waste of stone processing in the framework of Euro integration of Ukraine / V.Shamrai, V.Korobiichuk, R.Sobolevskyi // Вісник ЖДТУ. Серія : Технічні науки. - 2017. - № 2 (1). - С. 234-239.

9. Коробійчук $B$. Геометризація супутньої корисної копалини вумовах Лезниківського родовища гранітів та гірничо-геометричний аналіз його показників / В.Коробійчук // Вісник Національного університету водного господарства та природокористування. Серія : Технічні науки. - 2012. - № 58. - С. 175-184.

10. Дослідження шляхів мінімізації втрат при буровибуховому способі видобування блоків декоративного каменю / Р.В. Соболевський, О.О. Кісєль, В.В. Коробійчук, О.А. Зубченко // Вісник ЖДТУ. Серія : Технічні науки. - 2006. - № 4 (39). - С. 301-307.

11. A procedure for modeling the deposits of kaolin raw materials based on the comprehensive analysis of quality indicators / R.Sobolevskyi, A.Vaschuk, O.Tolkach et al. // Eastern European Journal of Advanced Technologies. Issue 3 (87). - P. 54-66.

12. Коробійчук В.В. Дослідження тріщинуватості Лезниківського родовища гранітів з перспективою видобутку блочної продукції / B.B. Коробійчук // Східно-європейський журнал передових технологій. - Харків : Технологічний центр, 2013. - Вип. 6/5 (66). - С. 23-27.

13. Korobiichuk V.V. European integration: treatment of stone processing enterprises waste in Ukraine / V.V. Korobiichuk, O.M. Sidorov, R.V. Sobolevskyi // Вісник ЖДТУ. Серія : Технічні науки. - 2017. - № 1 (79). C. $182-190$.

14. Evaluation of the effectiveness of natural stone surface treatment from Ukraine by mechanical and chemical methods / V.Korobiichuk, V.Shamrai, V.Levytskyi et al. // Rudarsko Geolosko Naftni Zbornik. - 2018. - Vol. 33, Issue 4. P. 15-22.

15. Optimization of the process of efficiency management of the primary kaolin excavation on the curved face of the conditioned area / V.Korobiichuk, R.Sobolevskyi, V.Levytskyi et al. // Rudarsko Geolosko Naftni Zbornik. - 2020. Vol. 35, Issue 1. - P. 123-137.

\section{References:}

1. Hanxleden, R., Botorabi, A. and Kupczyk, S. (1998), «A co-design approach for safety-critical automotive applications», IEEE Micro (Special Issue on Embedded Fault-Tolerant Systems), Vol. 18, pp. 66-79.

2. Kassakian, J.G. (2000), «Automotive electrical systems - The power electronics market of the future», in Proc. IEEE APEC 2000, Vol. 1, pp. 3-9.

3. Brown, G.M. and Koellner, W.G. (1999), «A GTO powered AC drive system increases the performance of offhighway haul trucks», in Conf. Rec. IEEE-IAS Annu. Meeting, Oct. 3-7, pp. 222-233.

4. Brown, G.M., Ebacher, B.J. and Koellner, W.G. (2000), «Increased productivity with AC drives for mining excavators und haul trucks», in Conf. Rec. IEEE-IAS Annu. Meeting, Vol. 1, pp. P28-P37.

5. Sacks, H.K., Cawley, J.C., Homce, G. and Yenchek, M. (2001), «Feasibility study to reduce injuries and fatalities caused by contact of cranes, drill rigs, and haul trucks with high tension lines», IEEE Trans. Ind. Applicat, Vol. 37, pp. 914-919.

6. Kryvoruchko, A.O., Korobijchuk, V.V. and Is'kov, S.S. (2012), «Rozrobka uzagal'nenoi' metodyky geometryzacii' masyviv pryrodnogo kamenju z metoju otrymannja kompleksnoi' modeli rodovyshha», Visnyk ZhDTU, No. 4 (63), pp. 190-202.

7. Korobiichuk, V., Kravets, V., Sobolevskyi R. et al. (2018), «Weakening of rock strength under the action of cyclic dynamic loads», Eastern European Journal of Advanced Technologies, Issue 2 (5), pp. 20-25.

8. Shamrai, V., Korobiichuk, V. and Sobolevskyi, R. (2017), «Management of waste of stone processing in the framework of Euro integration of Ukraine», Visnyk ZhDTU, Serija Tehnichni nauky, No. 2 (1), pp. 234-239.

9. Korobijchuk, V. (2012), «Geometryzacija suputn'oi' korysnoi' kopalyny vumovah Leznykivs'kogo rodovyshha granitiv ta girnycho-geometrychnyj analiz jogo pokaznykiv», Visnyk Nacional'nogo universytetu vodnogo gospodarstva ta pryrodokorystuvannja, Serija Tehnichni nauky, No. 58, pp. 175-184.

10. Sobolevs'kyj, R.V., Kisjel', O.O., Korobijchuk, V.V. and Zubchenko, O.A. (2006), «Doslidzhennja shljahiv minimizacii' vtrat pry burovybuhovomu sposobi vydobuvannja blokiv dekoratyvnogo kamenju», Visnyk ZhDTU, Serija Tehnichni nauky, No. 4 (39), pp. 301-307.

11. Sobolevskyi, R., Vaschuk, A., Tolkach, O. et al., «A procedure for modeling the deposits of kaolin raw materials based on the comprehensive analysis of quality indicators», Eastern European Journal of Advanced Technologies, Issue 3 (87), pp. 54-66. 
12. Korobijchuk, V.V. (2013), «Doslidzhennja trishhynuvatosti Leznykivs'kogo rodovyshha granitiv z perspektyvoju vydobutku blochnoi' produkcii'», Shidno-jevropejs'kyj zhurnal peredovyh tehnologij, Tehnologichnyj centr, Harkiv, Issue 6/5 (66), pp. 23-27.

13. Korobiichuk, V.V., Sidorov, O.M. and Sobolevskyi, R.V. (2017), «European integration: treatment of stone processing enterprises waste in Ukraine», Visnyk ZhDTU, Serija Tehnichni nauky, No. 1 (79), pp. 182-190.

14. Korobiichuk, V., Shamrai, V., Levytskyi, V. et al. (2018), «Evaluation of the effectiveness of natural stone surface treatment from Ukraine by mechanical and chemical methods», Rudarsko Geolosko Naftni Zbornik, Vol. 33, Issue 4. pp. 15-22.

15. Korobiichuk, V., Sobolevskyi, R., Levytskyi, V. et al. (2020), «Optimization of the process of efficiency management of the primary kaolin excavation on the curved face of the conditioned area», Rudarsko Geolosko Naftni Zbornik, Vol. 35, Issue 1, pp. 123-137.

Ковалевич Людмила Анатоліївна - старший викладач кафедри маркшейдерії Державного університету «Житомирська політехніка».

https://orcid.org/0000-0001-9158-2576.

Наукові інтереси:

- транспортні технології;

- відкриті гірничі роботи.

Левицький Володимир Григорович - кандидат технічних наук, доцент, доцент кафедри маркшейдерії Державного університету «Житомирська політехніка».

https://orcid.org/0000-0002-3892-5848.

Наукові інтереси:

- процеси гірничого виробництва;

- маркшейдерські роботи.

Білобров Дмитро Миколайович - аспірант кафедри розробки родовищ корисних копалин ім. проф. М.Т. Бакка, Державного університету «Житомирська політехніка».

Наукові інтереси:

- транспортні роботи;

- моделювання процесів гірничого виробництва.

Кириленко Ніна Павлівна - провідний спеціаліст Державного університету «Житомирська політехніка».

https://orcid.org/0000-0001-7222-9320.

Наукові інтереси:

- процеси гірничого виробництва;

- виймально-навантажувальне обладнання.

Шамрай Володимир Ігорович - кандидат технічних наук, доцент кафедри розробки родовищ корисних копалин ім. проф. М.Т. Бакка Державного університету «Житомирська політехніка».

https://orcid.org/0000-0001-9441-9379.

Наукові інтереси:

- процеси гірничого виробництва;

- обробка каменю. 